\title{
Efficacy of aqueous extracts of some solanaceous plants on juveniles mortality and egg hatching on the root knot nematode, Meloidogyne javanica under laboratory conditions
}

\author{
Abdel-Mageed M. A.*, Mahmoud N. A., El-Mesalamy A. F. \\ Agricultural Zoology and Nematology Department, Faculty of Agriculture, Al-Azhar University, Assiut, Egypt
}

\begin{abstract}
Aqueous extracts of black nightshade, Solanum nigrum; deadly nightshade, Atropa belladonna; Egyptian henbane, Hyoscyamus muticus; thorn apple, Datura innoxia; ashwagndha, Withania somnifera leaves and fruits of chili pepper, Capsicum frutescens were assessed on juvenile mortality and egg hatching of the root knot nematode, Meloidogyne javanica in vitro. The nematode mortalities were in the range of (54.33 to $100.0 \%$ ) in concentrations $\mathrm{S} / 16, \mathrm{~S} / 8$ and $\mathrm{S} / 4$ compared to distilled water $(1.33 \%)$ and increased with the increase of the exposure time from 24 to $72 \mathrm{hrs}$. Deadly nightshade and chili pepper extracts were the most effective against second stage juveniles of nematode at concentration of $S / 4$, followed by aqueous extracts of ashwagndha, thorn apple, black nightshade. Result showed that, the highest reduction in hatching inhibition percentage was recorded with concentration (S/4) of ashwagndha (97.63\%) followed by Egyptian henbane, deadly nightshade, black nightshade, thorn apple and chili pepper with inhibition percentages as $(95.42,94.60,92.87,79.61$ and $67.97 \%)$ respectively.
\end{abstract}

Keywords: solanaceous, Meloidogyne javanica, aqueous extracts, hatching and mortality.

*Corresponding author: Abdel-Mageed M. A.,

E-mail address: mohammed.abdo9999@gmail.com 


\section{Introduction}

Plant parasitic nematodes are one of the major problems in many parts of the world as well as soils of Nile valley and newly reclaimed sandy soils in desert of Egypt (Abd-Elgawad, 2013; Abd-Elgawad et al., 2012; Oteifa and El-Ginidi, 1982). Nowadays, nematologists all over the world are keeping searching for alternative control measures to avoid soil pollution with chemical nematicides and subsequently the hazardous effects due to its residues. Resistant cultivars, plant extracts and manuring the soil with natural organic materials are commended as alternative methods of agricultural pest control in integrated pest management programs. The nematicidal activity of botanical extracts of chili pepper fruits (Capsicum frutescens) were evaluated on the root-knot nematode, $M$. javanica in tomato plants in the greenhouse, and in a second step, to compare the best extracts for the reduction of the number of eggs and root galls with two products containing capsaicin, capsainoids and allyl isothiocyanate (Neves et al., 2009). the effect of leaf extract of (Withania somnifera) and (Datura metal) were evaluated by observing number of knots, shoot length, fresh shoot weight, root length and fresh root weight of the plant (Singh and Devi, 2012). The effects of plant extracts from Capsicum frutescens, Hyoscyamus niger were evaluated against RKNs on eggs, egg masses and $\mathrm{J}_{2} \mathrm{~S}$ of the $M$. incognita in laboratory conditions (Kepenekci et al., 2016). Leaf aqueous extracts of Datura metel, Datura innoxia were studied against the most devastating root-knot nematode $M$. incognita
(Nandakumar et al., 2017). Solanum nigrum (seeds) and Datura stramonium (shoots) were investigated against rootknot nematodes in terms of $\mathrm{J}_{2}$ paralysis and egg hatch inhibition (Oplos, 2018). The objective of this study was to test nematicidal activity of aqueous extracts representing six solanaceous plants for their potential toxicity against eggs and juveniles of the root knot nematode, $M$. javanica under laboratory conditions.

\section{Materials and methods}

Leaves of five solanaceous plants: black nightshade, Solanum nigrum; deadly nightshade, Atropa belladonna; Egyptian henbane, Hyoscyamus muticus; thorn apple, Datura innoxia; ashwagndha, Withania somnifera leaves and fruits of chili pepper, Capsicum frutescens were used. Plants materials collected randomly from plants grown in the experimental farm and gardens of Al-Azhar University, Assiut, Egypt except Egyptian henbane was collected from New Valley governorate. Plants parts were washed thoroughly under running tap water, cut into small pieces, shade dried and used for extraction. Dried plant materials homogenized to a fine powder then stored in airtight bottles. Fifty grams of each plant powder were extracted with $500 \mathrm{ml}$ of distilled water for $24 \mathrm{hrs}$. The suspension was filtered with Whatman No. 1 filter paper for each plant extract and considered as a standard solution (S) and diluted to (S/4), (S/8) and (S/16). The culture of root knot nematode, 
Meloidogyne javanica was maintained on potted eggplant planted inside the greenhouse. The infected plants uprooted, carefully washed in running tap water and egg-masses collected into Petri dishes containing distilled water. The evaluation was carried out in $5 \mathrm{~cm}$ clean Petri dishes in 3 replications for each treatment. The Petri dishes with distilled water was taken as control. 100-second stage juveniles $\left(\mathrm{J}_{2} \mathrm{~s}\right)$ of $M$. javanica were suspended in 10 $\mathrm{ml}$ of different extracts with dilutions $\mathrm{S} / 16, \mathrm{~S} / 8$ and $\mathrm{S} / 4$. All Petri dishes were kept at ambient temperature at $28 \pm 5{ }^{\circ} \mathrm{C}$. After 24, 48 and $72 \mathrm{hrs}$, the dead $\mathrm{J}_{2} \mathrm{~s}$ were counted and the percentage of juveniles' mortality were calculated according to the following formula:

Juveniles mortality $\%=\frac{\text { No. juveniles dead in the treatment }}{\text { Total No. juveniles were used in the treatment }} \times 100$

Five egg-masses medium size handpicked from the galls of eggplant were placed in each of Petri dishes containing $5 \mathrm{ml}$ of extracts with dilutions of $\mathrm{S} / 8$ and $\mathrm{S} / 4$. Egg-masses kept in distilled water served as control. Each treatment was replicated 3 times. After 7 days exposure, the numbers of juveniles hatched were counted and the percentages of egg hatched, and Inhibition were calculated using the following formulas:

Eggs hatched $\%=\frac{\text { No. Juveniles hatched in the treatment }}{\text { No. Juveniles hatched in control }} \times 100$

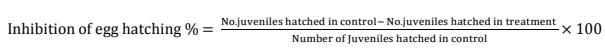

The randomized complete design was used in the experimental. Data were subjected to analysis of variance (ANOVA) using SPSS statistics. The means were compared according to Duncan's multiple range tests at $\mathrm{P} \leq 0.05$ (Duncan, 1955).

\section{Results}

The aqueous extracts of black nightshade (Solanum nigrum), deadly nightshade (Atropa belladonna), Egyptian henbane (Hyoscyamus muticus), chili pepper (Capsicum frutescens), thorn apple (Datura innoxia) and ashwagndha (Withania somnifera) were highly nematicidal effect to second stage juveniles of M. javanica in vitro (Table 1). The nematode mortality was in the range of (54.33 to $100.0 \%)$ in concentrations $\mathrm{S} / 16, \mathrm{~S} / 8$ and $\mathrm{S} / 4 \%$ compared to distilled water $(1.33 \%)$. Results revealed that, the nematode mortality with plant extracts were increased with the increase of the exposure time from 24 to 72 hrs. Deadly nightshade and chili pepper extracts were more effective against $\mathbf{J}_{2}$ of nematode at concentration $\mathrm{S} / 4$ followed by aqueous extracts of ashwagndha, thorn apple, black nightshade and Egyptian henbane were $(100,100,99,98.33,93$ and 75.67 $\%$ ), respectively, of exposure time $72 \mathrm{hrs}$. On the other hand, concentration S/16 recorded the lowest rate of juveniles mortalities in Egyptian henbane $(54.33 \%)$, black nightshade (65.33\%), ashwagndha (88\%), chili pepper (89\%), thorn apple (94.33\%) and deadly nightshade $(97.33 \%)$ respectively. Data presented in Table (2) indicated that, concentration $(\mathrm{S} / 4)$ of aqueous extracts was the highest of percentage hatch 
inhibition in ashwagndha (97.63 \%) followed by Egyptian henbane, deadly nightshade, black nightshade, thorn apple and chili pepper with percentage inhibition of egg hatching $(95.42,94.60$, $92.87,79.61$ and $67.97 \%$ ) respectively. While, aqueous extracts of plants with concentration $\mathrm{S} / 8$ showed the highest inhibition of egg-masses hatching in deadly nightshade $(89.99 \%)$ followed by ashwagndha $(88.21 \%)$, Egyptian henbane (84.42\%), black nightshade (78.64\%), thorn apple $(72.23 \%)$ and chili pepper $(67.97 \%)$ respectively.

Table (1): Effect of aqueous extracts of six solanaceous plants on percentage of second stage juveniles mortality of the rootknot nematode, Meloidogyne javanica.

\begin{tabular}{|l|c|c|c|c|}
\hline \multirow{2}{*}{ Materials } & \multirow{2}{*}{ Conc. } & \multicolumn{3}{|c|}{ Juveniles mortality after hrs $(\%)$} \\
\cline { 2 - 5 } & & 24 & 48 & 72 \\
\hline \multirow{3}{*}{$\begin{array}{l}\text { Black nightshade } \\
\text { Solanum nigrum) }\end{array}$} & $\mathrm{S} / 16$ & $37.33 \mathrm{~d}$ & $46.67 \mathrm{de}$ & $65.33 \mathrm{~cd}$ \\
\cline { 2 - 5 } & $\mathrm{S} / 8$ & $41.67 \mathrm{~cd}$ & $63.33 \mathrm{bc}$ & $75.00 \mathrm{bc}$ \\
\cline { 2 - 5 } $\begin{array}{l}\text { Deadly nightshade } \\
\text { (Atropa belladonna) }\end{array}$ & $\mathrm{S} / 4$ & $67.33 \mathrm{bc}$ & $75.67 \mathrm{~b}$ & $93.00 \mathrm{a}$ \\
\hline \multirow{3}{*}{$\begin{array}{l}\text { Egyptian henbane } \\
\text { (Hyoscyamus muticus) }\end{array}$} & $\mathrm{S} / 16$ & $64.67 \mathrm{bc}$ & $26.00 \mathrm{f}$ & $97.33 \mathrm{a}$ \\
\cline { 2 - 5 } & $\mathrm{S} / 8$ & $77.33 \mathrm{ab}$ & $30.00 \mathrm{f}$ & $98.33 \mathrm{a}$ \\
\cline { 2 - 5 } & $\mathrm{S} / 4$ & $94.67 \mathrm{a}$ & $34.00 \mathrm{ef}$ & $100.00 \mathrm{a}$ \\
\hline \multirow{2}{*}{$\begin{array}{l}\text { Chili pepper } \\
\text { (Capsicum frutescens) }\end{array}$} & $\mathrm{S} / 16$ & $54.67 \mathrm{bcd}$ & $45.33 \mathrm{de}$ & $54.33 \mathrm{~d}$ \\
\cline { 2 - 5 } & $\mathrm{S} / 8$ & $60.33 \mathrm{bcd}$ & $66.00 \mathrm{bc}$ & $66.67 \mathrm{~cd}$ \\
\cline { 2 - 5 } & $\mathrm{S} / 4$ & $76.67 \mathrm{ab}$ & $74.67 \mathrm{~b}$ & $75.67 \mathrm{bc}$ \\
\hline \multirow{2}{*}{$\begin{array}{l}\text { Thorn apple } \\
\text { (Datura innoxia) }\end{array}$} & $\mathrm{S} / 16$ & $46.00 \mathrm{~cd}$ & $53.33 \mathrm{~cd}$ & $89.00 \mathrm{ab}$ \\
\cline { 2 - 5 } & $\mathrm{S} / 8$ & $97.33 \mathrm{a}$ & $98.00 \mathrm{a}$ & $99.00 \mathrm{a}$ \\
\hline \multirow{2}{*}{$\begin{array}{l}\text { Ashwagndha } \\
\text { (Withania somnifera) }\end{array}$} & $\mathrm{S} / 4$ & $99.00 \mathrm{a}$ & $100.00 \mathrm{a}$ & $100.00 \mathrm{a}$ \\
\cline { 2 - 5 } & $\mathrm{S} / 16$ & $54.00 \mathrm{bcd}$ & $47.33 \mathrm{de}$ & $94.33 \mathrm{a}$ \\
\cline { 2 - 5 } & $\mathrm{S} / 8$ & $59.00 \mathrm{bcd}$ & $93.67 \mathrm{a}$ & $96.00 \mathrm{a}$ \\
\hline Distilled Water (Control) & $\mathrm{S} / 4$ & $79.33 \mathrm{ab}$ & $98.33 \mathrm{a}$ & $98.33 \mathrm{a}$ \\
\cline { 2 - 5 } & $\mathrm{S} / 16$ & $59.67 \mathrm{bcd}$ & $77.33 \mathrm{~b}$ & $88.00 \mathrm{ab}$ \\
\cline { 2 - 5 } & $\mathrm{S} / 8$ & $76.00 \mathrm{ab}$ & $91.67 \mathrm{a}$ & $93.33 \mathrm{a}$ \\
\hline
\end{tabular}

Values in each column followed by the same letters are no significant at $\mathrm{P}<0.05$ according to Duncan's multiple-range test.

Table (2): Effect of aqueous extracts of six solanaceous plants on hatching of root-knot nematode, Meloidogyne javanica egg masses.

\begin{tabular}{|l|c|c|c|c|}
\hline ds & Dose & Mean & Juveniles hatched (\%) & Inhibition (\%) \\
\hline \multirow{2}{*}{$\begin{array}{l}\text { Black nightshade } \\
\text { (Solanum nigrum) }\end{array}$} & $\mathrm{S} / 8$ & $345 \mathrm{cde}$ & 21.36 & 78.64 \\
\cline { 2 - 5 } $\begin{array}{l}\text { Deadly nightshade } \\
\text { (Atropa belladonna) }\end{array}$ & $\mathrm{S} / 4$ & $115 \mathrm{fg}$ & 7.13 & 92.87 \\
\hline \multirow{2}{*}{$\begin{array}{l}\text { Egyptian henbane } \\
\text { (Hyoscyamus muticus) }\end{array}$} & $\mathrm{S} / 8$ & $128 \mathrm{fg}$ & 7.94 & 92.06 \\
\cline { 2 - 5 } & $\mathrm{S} / 4$ & $87 \mathrm{fg}$ & 5.4 & 94.60 \\
\cline { 2 - 5 } $\begin{array}{l}\text { Chili pepper } \\
\text { (Capsicum frutescens) }\end{array}$ & $\mathrm{S} / 8$ & $252 \mathrm{ef}$ & 15.58 & 84.42 \\
\hline \multirow{2}{*}{$\begin{array}{l}\text { Thorn apple } \\
\text { (Datura innoxia) }\end{array}$} & $\mathrm{S} / 8$ & $74 \mathrm{~g}$ & 4.58 & 95.42 \\
\hline \multirow{2}{*}{$\begin{array}{l}\text { Ashwagndha } \\
\text { (Withania somnifera) }\end{array}$} & $\mathrm{S} / 8$ & $551 \mathrm{~b}$ & 30.78 & 69.22 \\
\hline & $\mathrm{S} / 4$ & $329 \mathrm{de}$ & 32.03 & 67.97 \\
\hline Distilled Water (Control) & $\mathrm{S} / 8$ & $190 \mathrm{efg}$ & 27.77 & 72.23 \\
\cline { 2 - 6 } & $\mathrm{S} / 4$ & $38 \mathrm{~g}$ & 11.79 & 89.61 \\
\hline
\end{tabular}

Values in each column followed by the same letters are no significant at $\mathrm{P}<0.05$ according to Duncan's multiple-range test. 


\section{Discussion}

In conclusion, the assessment results of land capability and land suitability for the selected crops helps in planning sustainable agriculture programs. Integration between geographic information systems (GIS), ASLE, and MicroLIES programs was undertaken in these soils to assess the land performance. The results of these soils indicated that the major soil limitations are soil texture, soil salinity, and low soil fertility characteristics, which can be improved using good management practices such as adding organic matter, fertilizers for upgrade the fertility, leaching the excess salt, and good agriculture practices for crops. These improvements will develop the potential suitability. Ultimately, from this study, it can be mentioned that the geostatistical approach and GIS are effective and strong tools for land capability and suitability studies and hence for sustainable planning of land use.

\section{References}

Abbasi, W. M., Ahmed, N., Zaki, J. M. and Shaukat, S. S. (2008), "Effect of Barleria acanthoides Vahl. on rootknot nematode infection and growth of infected okra and brinjal plants", Pakistan Journal of Botany, Vol. 40, pp. 2193-2198.

Abd-Elgawad, M. M. M. (2013), "Phytonematode damage, economic threshold and management with special reference to Egypt", Egyptian Journal of Agronematology, Vol. 12, pp. 159-176.
Adegbite, A. A. and Adesiyan, S. O. 2005), "Root extracts of plants to control root-knot nematode on edible soybean", World Journal of Agriculture Science, Vol. 1 pp. 1821.

Atanu, F. O., Ebiloma, U. G. and Ajayi, E. I. (2011), "A review of the pharmacological aspects of Solanum nigrum Linn", Biotechnology and Molecular Biology Review, Vol. 6, pp. 1-7.

Badia, A. D., Spina, A. A. and Vassalotti, G. (2017), "Capsicum annuum L.: An overview of biological activities and potential nutraceutical properties in humans and animals", Journal of Nutritional Ecology and Food Research, Vol. 4 pp. 1-11.

Duncan, D. B. (1955), "Multiple range and multiple $\mathrm{F}$ tests, Biometrics", Vol. 11, pp. 1-42.

Goel, S. R., Madan, V. K., Sharma, K. K. and Nandal, S. N. (2005), Nematicidal activity of various medicinal and aromatic plants under in vitro conditions, National Symposium on Recent Advances and Research Priorities in Indian Nematology, IARI, New Delhi, India, pp.23.

Haseeb, A. and Butoo, F. (1996), "Evaluation of nematicidal properties of some members of the family solanaceae", Bioresource Technology, Vol. 57, pp. 95-97.

Hussain, M. A., Mukhtar, T. and Kayani, 
M. Z. (2011), "Efficacy evaluation of Azadirachta indica, Calotropis procera, Datura stramonium and Tagetes erecta against root-knot nematodes Meloidogyne incognita", Pakistan Journal of Botany, Vol. 43, pp. 197-204.

Kepenekci, I., Erdoğuş, D. and Erdoğan, P. (2016), "Effects of some plant extracts on root-knot nematodes in vitro and in vivo conditions", Turkish Journal of Entomology, Vol. 40, pp. 3-14.

Nandakumar, A., Muthu, M.V., Sundararaju P. and Udayakumar R. (2017), "Nematicidal activity of aqueous leaf extracts of Datura metel, Datura innoxia and Brugmansia suaveolens", American Journal of Entomology, Vol. 1, pp. 39-45.

Neves, W. S., Freitas, L. G., Coutinho, M. M., Rosangela Dallemole-Giaretta (2009), "Nematicidal activity of extracts of red-chili chili pepper, mustard and garlic on Meloidogyne javanica in green house", Summa Phytopathologica, Vol. 35, pp. 255261.

Opareke, A. M., Dike, M. C. and Amatobi, C. I. (2005), "Field evaluation of extracts of five Nigerian species for control of post flowering insect pest of cowpea, Vigna unguiculata (L.) Walp.", Plant Protection Science, Vol. 41, pp. 1420.

Oplos, Ch., Eloh, K., Spiroudi, U.,
Pierluigi, C. and Ntalli, N. (2018), Nematicidal Weeds, Solanum nigrum and Datura stramonium", Journal of Nematology, Vol. 50, pp. 1-13.

Orisajo, S. B., Okeniyi, M. O., Fademi, O. A. and Dongo, L. N. (2007), "Nematicidal effects of water extracts of Acalypha ciliate, Jatropha gosssypifolia, Azadiractha indica and Allium ascalonicum on Meloidogyne incognita infection on cacao seedlings", Journal of Research Bioscience, Vol. 3, pp. 4953.

Oteifa, B. A. and El-Ginidi, D. M. (1982), Relative susceptibility of certain commercially important cultivars to existing biotypes of Meloidogyne incognita and M. javanica in NileDelta, Egypt, In: Proceedings of International Meloidogyne Project. Research and Planning Conference on Root-Knot Nematodes Meloidogyne spp., Region VII, pp. 157-169.

Saeed, M. R. M., Awadh, G. A. M., AlThobhani, M. A. and Aziza Taj AlDeen (2015), "In vitro nematicidal activity of ten plant extracts against juveniles of M. incognita", Egyptian Journal of Agronematology, Vol. 14 pp. 78-90.

Shahwar, D., Abid, M., Rehman, A. U., Maqbool, M. A. and Choudhary, M. I. (1995). Nematicidal compounds from D. fastuosa Eds. Rehman AU, Choudhary MA, Sheikhani MS, In the Proceedings $19^{\text {th }}$ IURC Symposium on the Chemistry of Natural 
Products, HEJ Resarch Institute of Chemistry, University of Karachi, Pakistan, pp. 171-179.

Sharma, N. and Trivedi, P. C. (2002), "Screening of leaf extracts of some plants for their nematicidal and fungicidal properties against Meloidogyne incognita and Fusarium oxysporum", Asian Journal of Experimental Science, Vol. 16, pp. 21-28.
Singh, S. P. and Devi, L. S. (2012), "Management of root-knot nematode, Meloidogyne incognita on brinjal (Solanum melongena L.) with some plant extracts", Current Nematology, Vol. 23, pp. 65-72. 